\title{
Analisis Karakteristik Elektrik Onggok Singkong sebagai Pasta Bio-Baterai
}

\author{
Tri Sumanzaya ${ }^{(1)^{*}}$, Amir Supriyanto ${ }^{(1)}$, dan Gurum A. Pauzi ${ }^{(1)}$ \\ (1) Jurusan Fisika FMIPA Universitas Lampung \\ Jl.Prof. Dr. Soemantri Brojonegoro No.1 Gedung Meneng Bandar Lampung 35145 \\ *E-mail: trisumanzaya93@gmail.com
}

Diterima (10 Mei 2019), Direvisi (24 Mei 2019)

\begin{abstract}
Bio-battery is a battery with paste that is made of natural materials. Bio-battery produce electrical power by using electrolyte cassava pulp and Cu-Zn electrode. Design of bio-batteries are made by 20 cell of dry cell battery type R2OS IEC/UM-1/D 1,5 volt and arranged in series. Cassava pulp variation are new cassava pulp and pulp with fermentation for 48 hours, 96 hours, and 144 hours. The measurement of the electrical characteristics using 7 watt LED DC for 12 hours. The maximum voltage when the load is released which genereted by new cassava pulp is 16,76 volt, fermented for 48 hours is 19,28 volt, fermented for 96 hours is 20,00 volt, and fermented for 144 hours is 20,30 volt. The variety of cassava pulp which has the best electrical characteristics is fermented cassava pulp for 144 hours. It could turn on the lamp with bright lights. The results showed that the longer the fermentation time of cassava pulp caused the electrical conductivity was increased.
\end{abstract}

Keywords: Bio-battery, cassava pulp, the electrical characteristics.

\begin{abstract}
Abstrak. Bio-baterai adalah baterai dengan pasta yang berasal dari bahan alam yang ramah lingkungan. Biobaterai mampu menghasilkan daya listrik dengan menggunakan elektrolit onggok singkong dan elektroda $\mathrm{Cu}$ $\mathrm{Zn}$. Desain alat dibuat dari baterai $d r y$ cell tipe R20S IEC/UM-1/D tegangan 1,5 volt sebanyak 20 buah yang dirangkai secara seri. Elektrolit yang digunakan adalah onggok singkong baru, onggok singkong fermentasi 48 jam, 96 jam, dan 144 jam. Pengukuran karakteristik elektrik onggok singkong dengan menggunakan beban lampu LED DC $12 \mathrm{~V} 7$ watt selama $12 \mathrm{jam}$. Tegangan maksimum saat tidak diberi beban yang dihasilkan onggok singkong baru sebesar 16,76 volt, fermentasi 48 jam sebesar 19,28 volt, fermentasi 96 jam sebesar 20,00 volt, dan fermentasi 144 jam sebesar 20,30 volt. Jenis onggok singkong yang memiliki karakteristik elektrik terbaik adalah onggok singkong fermentasi 144 jam. Onggok singkong tersebut mampu menyalakan lampu dengan terang. Penelitian ini menunjukkan semakin lama waktu fermentasi onggok singkong menyebabkan koduktivitas listrik meningkat.
\end{abstract}

Kata kunci: Bio-baterai, onggok singkong, karakteristik elektrik.

\section{PENDAHULUAN}

Onggok singkong merupakan hasil sampingan dari pengolahan singkong menjadi tapioka. Sebagai provinsi dengan produksi singkong terbesar di Indonesia, Lampung mampu memproduksi singkong sebesar 7.387.084 ton pada tahun 2015 [1]. Sebagian besar singkong diolah menjadi tapioka, sehingga onggok yang dihasilkan sangat melimpah. Menurut Dinas Pertanian dan Ketahanan Pangan
Provinsi Lampung, setiap produksi satu ton singkong menjadi tepung tapioka akan menghasilkan $11,4 \%$ onggok.

Onggok singkong mangandung asam sianida (HCN). HCN merupakan merupakan salah satu elektrolit yang dapat menghasilkan listrik [2]. Kandungan HCN pada onggok singkong sebesar 175 ppm, sedangkan dalam bentuk kering kandungan HCN pada onggok singkong mencapai 77,56-94,31 ppm [3]. Sehingga memungkinkan onggok singkong mampu 
menghasilkan arus listrik. Dari sifat kelistrikan yang terkandung dalam onggok dapat dimanfaatkan sebagai sumber energi alternatif berupa bio-baterai.

Bio-Baterai adalah baterai dengan pasta yang berasal dari bahan alam yang ramah lingkungan dan tidak mengandung zat kimia bernahaya. Prinsip bio-baterai hanya melibatkan transportasi elektron antara dua elektroda yang dipisahkan oleh medium konduktif (elektrolit) serta memberikan kekuatan gerak listrik berupa potensial listrik dan arus [4].

Pengembangan bio-baterai telah diteliti oleh Muhlisin dkk [5] dengan memanfaat limbah organik yaitu kulit pisang dan kulit durian sebagai pengganti pasta baterai bekas. Nilai tegangan yang dihasilkan bio-baterai kulit pisang lebih besar dibandingkan dengan bio-baterai kulit durian, yaitu $1,12 \mathrm{~V}$ untuk kulit pisang dan 0,99 $\mathrm{V}$ untuk kulit durian. Sementara, Irsan dkk [6] menganalisa karakteristik elektrik kulit singkong sebagai pengganti sumber energi listrik untuk mengisi baterai telpon genggam. Penelitian juga dilakukan oleh Hendri dkk [7] yaitu pengaruh jenis kulit pisang dan variasi waktu fermentasi terhadap kelistrikan dari sel accu. Jenis kulit pisang terbaik sebagai bio-baterai yaitu kulit pisang ambon dengan waktu fermentasi 196 jam, dihasilkan tegangan sebesar 3,70 volt dan kuat arus sebesar 33,08 mA. Lama waktu fermentasi mengakibatkan nilai $\mathrm{pH}$ kulit singkong menjadi lebih kecil. Semakin asam larutan elektrolit, maka konsentrasi ion hidrogen dalam larutan semakin tinggi dan hantaran arus dari anoda ke katoda semakin besar [8]. Hal ini diakibatkan aktivitas organisme dalam larutan elektrolit meningkat, sehingga menyebabkan proses transfer elektron terjadi dengan cepat dan menghasilkan tegangan dan kuat arus yang lebih besar.

Berdasarkan urian tersebut, pada penelitian ini dilakukan untuk mengetahui karakterteristik elektrik bio-baterai onggok singkong dengan menggunakan elektroda tembaga $(\mathrm{Cu})$ dan seng $(\mathrm{Zn})$. Selain itu, penelitian ini dilakukan untuk mengetahui pengaruh jenis onggok singkong baru dan onggok singkong fermentasi dan lama waktu fermentasi terhadap karakteristik elektrik yang dihasilkan.

\section{METODE PENELITIAN}

Alat-alat yang digunakan dalam penelitian ini adalah multimeter digital, pH meter, tang, solder, timbangan, kabel, timbal, dan penjepit buaya. Sementara bahan-bahan yang digunakan baterai silinder bekas, tembaga, lampu LED 7 watt, dan onggok singkong baru, onggok singkong fermentasi 48 jam, 96 jam dan 144 jam.

\section{Pembuatan Bio-Baterai}

Media uji terbuat dari baterai bekas jenis dry cell merk ABC R20S IEC/UM-1/D tegangan sebesar 1,5 volt dengan ukuran diameter $34,2 \mathrm{~mm}$ dan tinggi $61,5 \mathrm{~mm}$ dikeluarkan pasta mangan oksida yang ada dalam baterai. Kemudian baterai dibersihkan menggunakan aquades, lalu dipasang kabel pada bagian bawah baterai mengunakan solder. Selain sebagai media uji, seng $(\mathrm{Zn})$ baterai berfungsi sebagai elektroda negaif.

Sedangkan elektroda positif yang digunakan adalah tembaga $(\mathrm{Cu})$ dengan panjang 7,5 cm. Selanjutnya masingmasing baterai diisi kembali dengan pasta onggok singkong yang diperoleh dari limbah pengolahan tepung tapioka sebanyak 40 gram dan dipasangkan elektroda tembaga diposisi tengah baterai yang dapat dilihat pada Gambar 1 (a). Kemudian 20 buah bio-baterai yang telah terisi pasta onggok singkong dirangkai secara seri seperti pada Gambar 1 (b). 


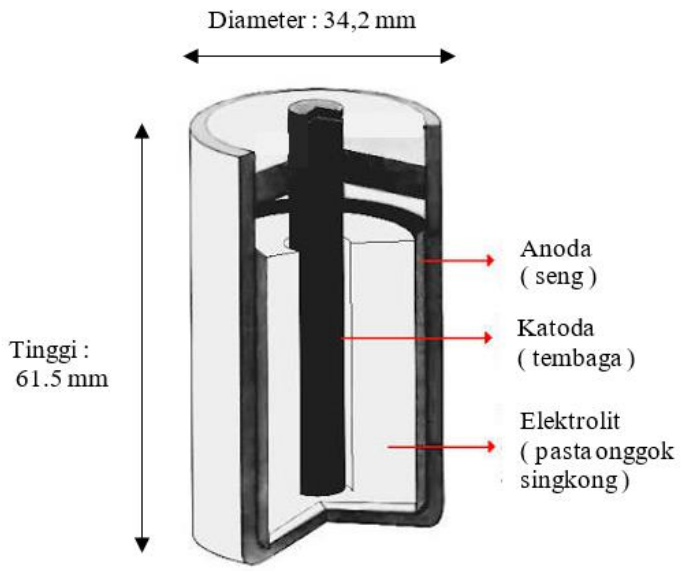

(a)

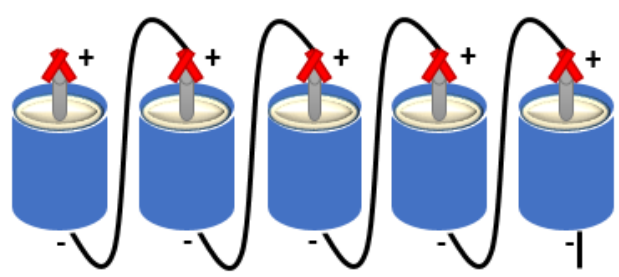

(b)

Gambar 1. (a) Media uji (bio-baterai), (b) Biobaterai yang dirangkai seri.

\section{Pengujian Alat}

Pengujian karakteristik elektrik onggok singkong dilakukan dengan mengukur tegangan saat beban dilepas $\left(\mathrm{V}_{\mathrm{bl}}\right)$, saat diberi beban $\left(\mathrm{V}_{\mathrm{b}}\right)$, dan arus $(\mathrm{I})$ yang mengalir menggunakan multimeter digital seperti yang ditunjukkan pada Gambar 2. Pengujian alat dilakukan dengan memberikan beban lampu LED DC 7 watt selama 12 jam dalam rentang pengukuran setiap 1 jam dengan 7 kali pengulangan. Selain mengukur karakteristik elektrik onggok singkong, dilakukan pengukuran $\mathrm{pH}$ atau derajat keasaaman pasta onggk singkong baru, fermentasi 48 jam, 96 jam, dan 144 jam. Setelah diperoleh data karakteristik elektrik onggok singkong, selanjutnya dilakukan perhitungan daya dan hambatan dalam yang dihasilkan rangkaian biobaterai.

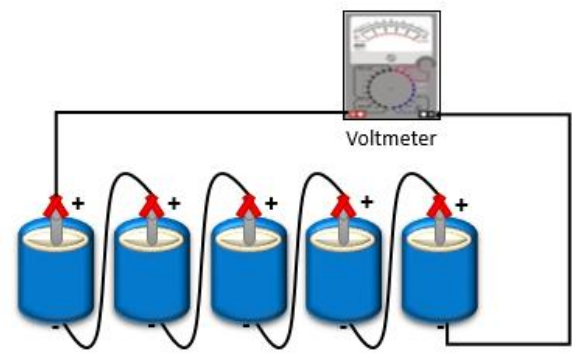

(a)

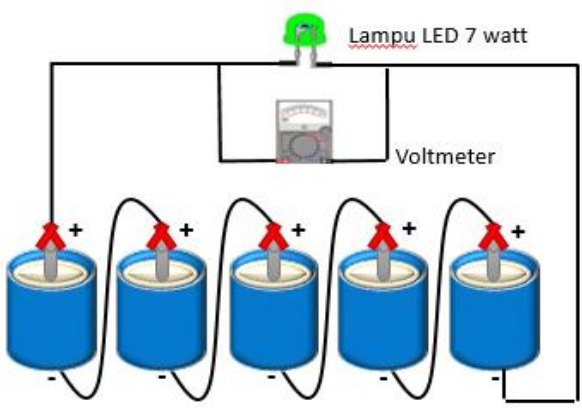

(b)

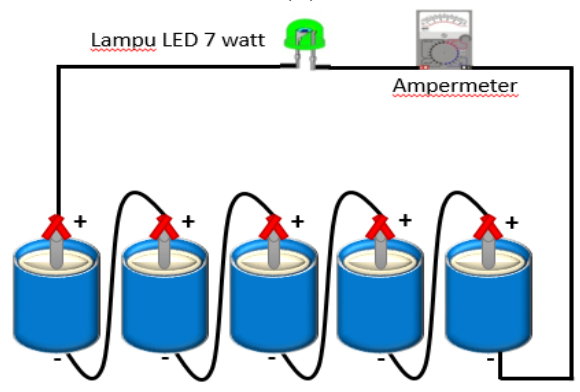

(c)

Gambar 2. Desain bio-baterai saat pengujian karakteristik elektrik onggok singkong, (a) Pengukuran tegangaan saat tidak diberi beban $\left(\mathrm{V}_{\mathrm{bl}}\right)$, (b) Pengukuran tegangan saat diberi beban $\left(\mathrm{V}_{\mathrm{b}}\right)$, dan (c) Pengukuran kuat arus (I).

\section{HASIL DAN PEMBAHASAN}

Pada penelitian ini dilakukan analisis pengaruh jenis onggok dan variasi waktu fermentasi terhadap karakteristik elektrik dari limbah onggok singkong. Analisis karakteristik meliputi tegangan, kuat dan arus. Variasi waktu fermentasi meliputi 48 jam, 96 jam, dan 144 jam.

Metode fermentasi onggok singkong yang digunakan pada penelitian ini yaitu fermentasi spontan. Fermentsi spontan adalah fermentasi yang tidak ditambahkan mikroorganisme dalam bentuk starter atau ragi dalam proses pembuatannya. 
Pengukuran derajat keasaman atau $\mathrm{pH}$ onggok singkong menggunakan $\mathrm{pHmeter}$ digital dengan model $\mathrm{pH}-02$ auto calibration. $\mathrm{pH}$ yang diukur adalah $\mathrm{pH}$ awal pengujian dan $\mathrm{pH}$ setelah pengujian untuk masing-masing onggok singkong dapat dilihat pada Tabel 1. Sedangkan pengukuran karakteristik elektrik biobaterai onggok singkong menggunakan multimeter digital.

Berdasarkan nilai potensial reduksi deret volta menunjukkan bahwa nilai beda potensial tembaga sebesar $+0,34$ volt, dan nilai beda potensial seng sebesar $-0,76$ volt [9]. Sehingga nilai beda potensial yang dihasilkan dari rangkaian kedua elektroda tersebut sebesar 1,1 volt. Sementara itu, hasil penelitian diperoleh nilai potensial listrik rata-rata setiap satu bio-baterai onggok singkong baru sebesar 0,81 volt, bio-baterai onggok singkong fermentasi 48 jam sebesar 0,87 volt, biobaterai onggok singkong fermentasi 96 jam sebesar 0,99 volt, dan bio-baterai onggok singkong fermentasi 144 jam sebesar 1,01 volt. Sementara itu, hasil penelitian nilai potensial listrik dari 20 buah bio-baterai dirangkai seri dapat dilihat pada Tabel 2 dan Tabel 3 dengan grafik perbandingan nilai potensial keempat jenis onggok singkong seperti pada Gambar 3 dan Gambar 4.

Tabel 1.Derajat keasaman $\mathrm{pH}$ onggok singkong.

\begin{tabular}{lcc}
\hline \multicolumn{1}{c}{$\begin{array}{c}\text { Jenis Onggok } \\
\text { Singkong }\end{array}$} & $\begin{array}{c}\mathrm{pH} \\
\text { awal }\end{array}$ & $\begin{array}{c}\mathrm{pH} \\
\text { akhir }\end{array}$ \\
\hline Baru & 8,50 & 7,10 \\
Fermentasi 48 jam & 6,79 & 6,50 \\
Fermentasi 96 jam & 6,39 & 6,10 \\
Fermentasi 144 jam & 5,89 & 5,77 \\
\hline
\end{tabular}

Tabel 2.Tegangan saat beban dilepas $\left(\mathrm{V}_{\mathrm{bl}}\right)$ dari

\begin{tabular}{ccccc}
\multicolumn{5}{c}{ keempat jenis onggok singkong. } \\
\hline $\begin{array}{c}\text { Waktu } \\
\text { (Jam) }\end{array}$ & $\begin{array}{c}\text { Vbl1 } \\
\text { (volt) }\end{array}$ & $\begin{array}{c}\text { Vbl2 } \\
\text { (volt) }\end{array}$ & $\begin{array}{c}\text { Vbl3 } \\
\text { (volt) }\end{array}$ & $\begin{array}{c}\text { Vbl4 } \\
\text { (volt) }\end{array}$ \\
\hline 0 & 16,45 & 15,23 & 19,00 & 20,00 \\
1 & 15,65 & 15,39 & 19,78 & 20,00 \\
2 & 15,90 & 15,84 & 19,82 & 20,00 \\
3 & 15,86 & 16,25 & 19,95 & 20,10 \\
4 & 15,16 & 16,43 & 19,97 & 20,10 \\
\hline
\end{tabular}

\begin{tabular}{ccccc}
\hline $\begin{array}{c}\text { Waktu } \\
\text { (Jam) }\end{array}$ & $\begin{array}{c}\text { Vbl1 } \\
\text { (volt) }\end{array}$ & $\begin{array}{c}\text { Vbl2 } \\
\text { (volt) }\end{array}$ & $\begin{array}{c}\text { Vbl3 } \\
\text { (volt) }\end{array}$ & $\begin{array}{c}\text { Vbl4 } \\
\text { (volt) }\end{array}$ \\
\hline 5 & 16,05 & 16,94 & 19,96 & 20,10 \\
6 & 16,07 & 17,82 & 19,95 & 20,14 \\
7 & 16,09 & 18,09 & 19,97 & 20,20 \\
8 & 16,08 & 18,24 & 19,97 & 20,20 \\
9 & 16,44 & 18,92 & 19,98 & 20,20 \\
10 & 16,50 & 19,23 & 20,00 & 20,23 \\
11 & 16,76 & 19,28 & 20,00 & 20,30 \\
12 & 16,58 & 19,27 & 20,00 & 20,30 \\
\hline
\end{tabular}

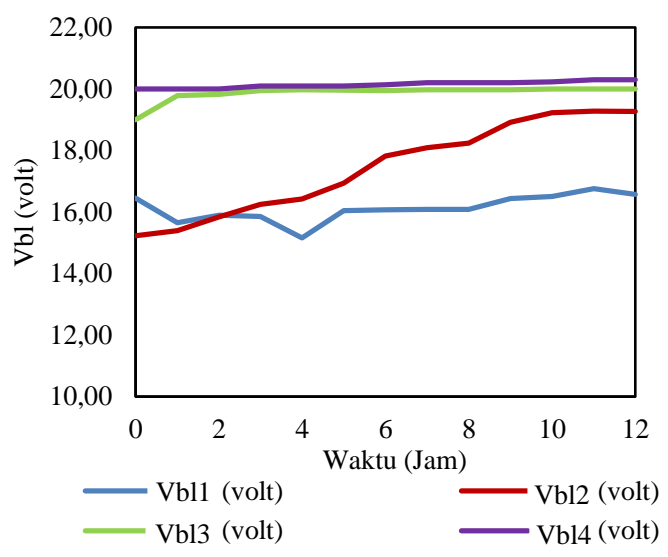

Gambar 3. Grafik perbandingan $\mathrm{V}_{\mathrm{bl}}$ keempat jenis onggok singkong terhadap waktu.

Gambar 3 menunjukkan tegangan bio-baterai onggok singkong fermentasi 48 jam mengalami peningkatan signifikan, dikarenakan adanya proses fermentasi. Sementara tegangan bio-baterai onggok singkong fermentasi 144 jam cenderung stabil dan nilai tegangan terbesar.

Tabel 3.Tegangan saat diberi beban $\left(\mathrm{V}_{\mathrm{b}}\right)$ dari keempat jenis onggok singkong.

\begin{tabular}{ccccc}
\hline $\begin{array}{c}\text { Waktu } \\
\text { (Jam) }\end{array}$ & $\begin{array}{c}\text { Vb1 } \\
\text { (volt) }\end{array}$ & $\begin{array}{c}\text { Vb2 } \\
\text { (volt) }\end{array}$ & $\begin{array}{c}\text { Vb3 } \\
\text { (volt) }\end{array}$ & $\begin{array}{c}\text { Vb4 } \\
\text { (volt) }\end{array}$ \\
\hline 0 & 7,58 & 7,62 & 7,70 & 7,72 \\
1 & 7,54 & 7,56 & 7,73 & 7,73 \\
2 & 7,55 & 7,59 & 7,69 & 7,72 \\
3 & 7,56 & 7,57 & 7,69 & 7,73 \\
4 & 7,57 & 7,57 & 7,64 & 7,72 \\
5 & 7,54 & 7,57 & 7,68 & 7,73 \\
6 & 7,55 & 7,62 & 7,68 & 7,73 \\
7 & 7,57 & 7,6 & 7,69 & 7,73 \\
8 & 7,58 & 7,58 & 7,69 & 7,74 \\
9 & 7,58 & 7,57 & 7,69 & 7,74 \\
10 & 7,59 & 7,61 & 7,69 & 7,74 \\
11 & 7,58 & 7,58 & 7,69 & 7,74 \\
12 & 7,58 & 7,62 & 7,69 & 7,75 \\
\hline
\end{tabular}




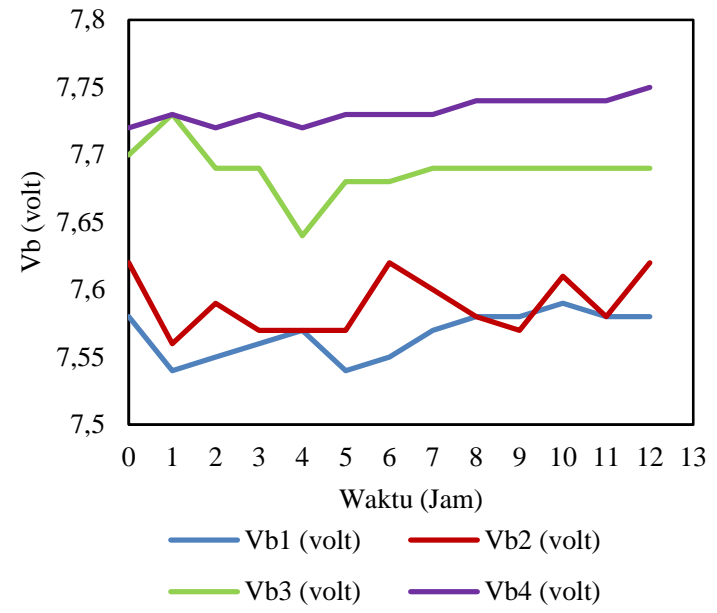

Gambar 4. Grafik perbandingan $V_{b}$ keempat jenis onggok singkong terhadap waktu.

Gambar 4 menunjukkan perubahan nilai tegangan saat diberi beban lampu LED 7 watt dari keempat jenis bio-baterai onggok singkong tidak stabil. Namun pada bio-baterai onggok singkong fermentasi 144 jam, tegangan $\left(\mathrm{V}_{\mathrm{b} 4}\right)$ mengalami peningkatan yang stabil dan nilai tegangan yang dihasilkan lebih besar dibandingkan tiga jenis bio-baterai lainnya.

Hasil penelitian untuk karakteristik elektrik arus dapat dilihat pada Tabel 4 dengan grafik perbandingan kuat arus dari keempat jenis bio-baterai seperti Gambar 5.

Tabel 4.Kuat arus (I) dari keempat jenis onggok singkong.

\begin{tabular}{ccccc}
\hline $\begin{array}{c}\text { Waktu } \\
(\mathbf{J a m})\end{array}$ & $\begin{array}{c}\text { I 1 } \\
(\mathbf{m A})\end{array}$ & $\begin{array}{c}\text { I 2 } \\
(\mathbf{m A})\end{array}$ & $\begin{array}{c}\text { I 3 } \\
(\mathbf{m A})\end{array}$ & $\begin{array}{c}\text { I 4 } \\
(\mathbf{m A})\end{array}$ \\
\hline 0 & 0,234 & 0,294 & 0,598 & 0,739 \\
1 & 0,236 & 0,223 & 0,603 & 0,745 \\
2 & 0,215 & 0,251 & 0,616 & 0,718 \\
3 & 0,215 & 0,235 & 0,618 & 0,739 \\
4 & 0,261 & 0,22 & 0,580 & 0,719 \\
5 & 0,234 & 0,24 & 0,592 & 0,746 \\
6 & 0,218 & 0,264 & 0,601 & 0,747 \\
7 & 0,231 & 0,274 & 0,605 & 0,749 \\
8 & 0,243 & 0,285 & 0,610 & 0,751 \\
9 & 0,271 & 0,275 & 0,612 & 0,754 \\
10 & 0,272 & 0,27 & 0,637 & 0,753 \\
11 & 0,286 & 0,298 & 0,615 & 0,759 \\
12 & 0,284 & 0,31 & 0,62 & 0,762 \\
\hline
\end{tabular}

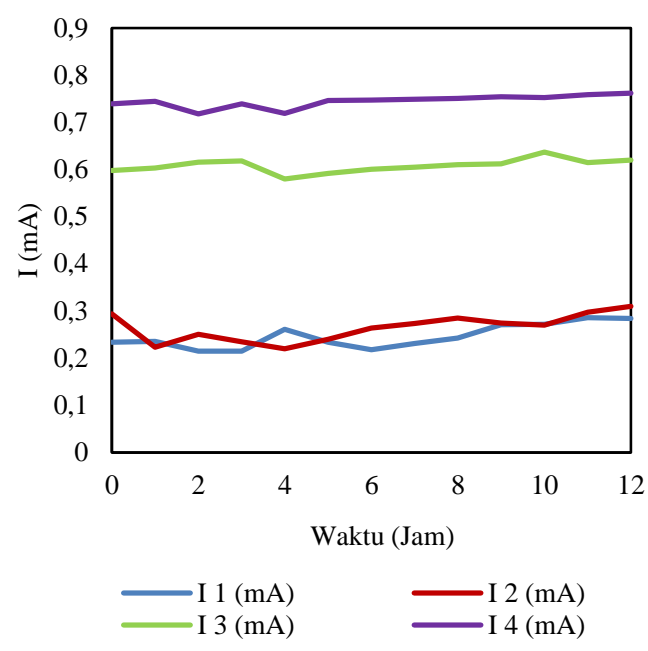

Gambar 5. Grafik perbandingan I keempat jenis onggok singkong terhadap waktu.

Gambar 5 menunjukkan bahwa arus yang dihasil mengalami peningkatan yang cukup stabil. Sementara itu, bio-baterai onggok singkong fermentasi 144 jam menghasilkan kuat arus yang lebih besar dibandingkan ketiga jenis bio-baterai lainnya. Perbandingan nilai arus disebabkan karena jumlah ion-ion pada masing-masing bio-baterai berbeda. Hal ini menunjukkan semakin lama onggok singkong difermentasi, maka karakteristik elektrik kuat arus (I) yang dihasilkan semakin meningkat.

Daya dihasilkan dari hasil perkalian antara tegangan saat diberi beban ( $\mathrm{Vb}$ ) dengan kuat arus (I). Hasil pengujian daya (P) dari keempat jenis onggok singkong dapat dilihat pada Tabel 5 dan perbandingan nilai daya dari keempat jenis onggok singkong seperti pada Gambar 6.

Gambar 6 menunjukkan nilai daya yang dihasilkan dari masing-masing biobaterai onggok singkong mengalami peningkatan yang stabil. Berdasarkan data yang diperoleh, nilai daya terbesar dihasilkan bio-baterai onggok singkong fermentasi 144 jam, sedangkan nilai daya terkecl dihasilkan bio-baterai onggok singkong baru. 
Tabel 5. Daya listrik (P) dari keempat jenis

\begin{tabular}{|c|c|c|c|c|}
\hline $\begin{array}{l}\text { Waktu } \\
\text { (Jam) }\end{array}$ & $\begin{array}{c}\text { P1 } \\
(\mathrm{mW})\end{array}$ & $\begin{array}{c}\text { P2 } \\
(\mathrm{mW})\end{array}$ & $\begin{array}{c}\text { P3 } \\
(\mathrm{mW})\end{array}$ & $\begin{array}{c}\mathrm{P4} \\
(\mathrm{mW})\end{array}$ \\
\hline 0 & 1,77 & 2,24 & 4,60 & 5,71 \\
\hline 1 & 1,78 & 1,69 & 4,66 & 5,76 \\
\hline 2 & 1,62 & 1,91 & 4,74 & 5,54 \\
\hline 3 & 1,63 & 1,78 & 4,75 & 5,71 \\
\hline 4 & 1,98 & 1,67 & 4,43 & 5,55 \\
\hline 5 & 1,76 & 1,82 & 4,55 & 5,77 \\
\hline 6 & 1,65 & 2,01 & 4,62 & 5,77 \\
\hline 7 & 1,75 & 2,08 & 4,65 & 5,79 \\
\hline 8 & 1,84 & 2,16 & 4,69 & 5,81 \\
\hline 9 & 2,05 & 2,08 & 4,71 & 5,84 \\
\hline 10 & 2,06 & 2,05 & 4,90 & 5,83 \\
\hline 11 & 2,17 & 2,26 & 4,73 & 5,87 \\
\hline 12 & 2,15 & 2,36 & 4,77 & 5,91 \\
\hline
\end{tabular}

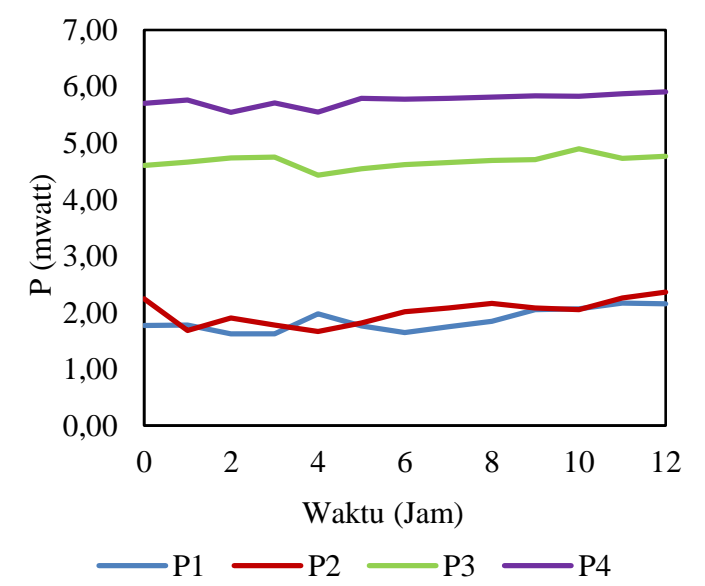

Gambar 6. Grafik perbandingan Pkeempat jenis onggok singkong terhadap waktu.

Jika konsentrasi ion $\mathrm{H}^{+}$pada suatu larutan meningkat maka ion $\mathrm{CN}^{-}$akan menurun dan ion $\mathrm{H}^{+}$dapat dengan mudah bergerak didalam larutan, sehingga larutan tersebut besifat asam dan konduktivitas listrik meningkat [10]. Berdasarkan hasil pengujian menunjukkan lama waktu fermentasi onggok singkong berpengaruh terhadap nilai $\mathrm{pH}$ dan karakteristik elektrik yng dihasilkan. Pada Tabel 1, data pengukuran $\mathrm{pH}$ awal pasta onggok singkong baru adalah 8,50 dan $\mathrm{pH}$ akhir setelah pengujian bio-baterai onggok singkong baru selama 12 jam mengalami penurunan sebesar 7,10 . Penurunan nilai pH pasta onggok singkong ini disebabkan

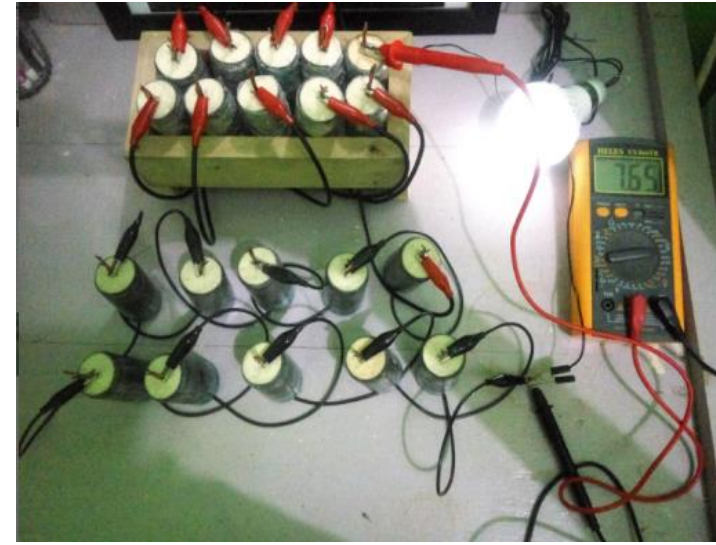

Gambar 7. Pengujian karakteristik elektrik biobaterai onggok singkong.

karena aktivitas mikroorganisme dan konsentrasi ion-ion $\mathrm{H}^{+}$pada pasta onggok singkong meningkat dan konsentrasi ionion $\mathrm{CN}^{-}$menurun, sehingga pasta onggok singkong berisifat asam dan ion-ion $\mathrm{H}^{+}$ dengan mudah bergerak didalam pasta onggok singkong. Reaksi ionisasi terjadi ketika pasta ongok singkong bersentuhan dengan unsur seng dan tembaga, sehingga terjadi aliran elektron yang menghasilkan nilai arus dan tegangan. Semakin lama waktu fermentasi menyebabkan arus dan tegangan yang dihasilkan oleh rangkaian bio-baterai onggok singkong semakin besar dan mampu menyalakan lampu LED seperti pada Gambar 7.

Hasil pengujian karakteristik elektrik terbaik dihasilkan oleh bio-baterai onggok singkong fermentasi 144 jam, yaitu $\mathrm{V}_{\mathrm{bl}}$ maks sebesar 20,30 volt, $\mathrm{V}_{\mathrm{b}}$ maks sebesar 7,75 volt, I maks sebesar 0,762 ampere, dan P maks sebesar 5,91 mwatt. Selain itu, rangkaian bio-baterai onggok singkong fermentasi 144 jam mampu menyalakan lampu LED DC 7 watt dengan nyala terang dibandingkan ketiga jenis biobaterai onggok singkong lainnya.

\section{KESIMPULAN}

Berdasarkan hasil pengujian dan analisis yang telah dilakukan dapat disimpulkan bahwa bio-baterai onggok singkong dengan elektroda $\mathrm{Cu}-\mathrm{Zn}$ mampu 
menghasilkan daya listrik dan menyalakan lampu LED DC 7 watt. Onggok singkong fermentasi 144 jam dihasilkan tegangan saat beban lepas $\left(\mathrm{V}_{\mathrm{bl}}\right)$, kuat arus (I) dan daya $(\mathrm{P})$ lebih besar dibandingkan dengan ketiga jenis onggok singkong lainnya. Hal ini menunjukan lama waktu fermentasi pasta onggok singkong menyebabkan $\mathrm{pH}$ turun sehingga konduktivitas listrik semakin meningkat. Penurunan $\mathrm{pH}$ disebabkan konsentrasi ion-ion $\mathrm{H}^{+}$pada onggok singkong meningkat, sehingga ion-ion $\mathrm{H}^{+}$bergerak dengan mudah dan mengakibatkan tegangan dan arus yang dihasilkan meningkat.

\section{DAFTAR PUSTAKA}

[1] Badan Pusat Statistik, "Produksi Ubi Kayu Menurut Provinsi (ton), 19932015", 9 September 2015. Tersedia : http://www.bps.go.id/dynamictable/2 015/09/09/880/produksi-ubi-kayumenurut-provinsi-ton-1993-2015. html. [Diakses 11 Maret 2018].

[2] Brady, J., Kimia Universitas Asas dan Struktur Jilid 1, Tangerang: Binarupa Aksara Publisher, 1999.

[3] Afrian, F.A., Liman, dan Tantalo, S., "Survei Populasi Kapang dan Kadar HCN pada Onggok Singkong dengan Proses Pengeringan yang Berbeda di Provinsi Lampung", Jurnal Ilmiah Peternakan Terpadu, vol. 2, no. 2, pp. 70-74, 2014.

[4] Kartawidjaja, M.A., Abdurrochman, A., dan Rumeksa, E., "Pencarian Parameter Bio-Baterai Berbasis Asam Sitrat (C6H8O7)," in Prosiding, Seminar Nasional dan Teknologi II, 2008.

[5] Muhlisin, M., Soedjarwanto, N., dan Komarudin, M., "Pemanfaatan Sampah Kulit Pisang dan Kulit
Durian sebagai Bahan Alternatif Pengganti Pasta Batu Baterai”, Jurnal Rekayasa dan Teknologi Elektro, vol. 9, no. 3, pp. 137-146, Sept. 2015.

[6] Irsan, Supriyanto, A., dan Surtono, A., "Analisis Karakteristik Elektrik Limbah Kulit Singkong (Manihot esculenta Crantz) sebagai Sumber Energi Listrik Alternatif Terbarukan untuk Mengisi Baterai Telepon Genggam", Jurnal Teori dan Aplikasi Fisika, vol. 5, no. 1, pp. 9-18, Jan. 2017.

[7] Hendri, Y.N., Gusnedi, dan Ratnawulan, "Pengaruh Jenis Kulit Pisang dan Variasi Waktu Fermentasi terhadap Kelistrikan dari Sel Accu dengan Menggunakan Larutan Kulit Pisang", Pillar of Physics vol. 6, pp. 97-104, Okt. 2015.

[8] Andinata, F., Destyorini, F., Sugiarti, E., dan Munasir, "Pengaruh $\mathrm{pH}$ Larutan Elektrolit terhadap Tebal Lapisan Elektroplating Nikel pada Baja ST 37", Jurnal Penelitian Fisika dan Aplikasinya (JPFA), vol. 2, no. 2, pp. 48-52, Des. 2012.

[9] Silbergbreg, M., Chemistry, The Moleculer Nature of Matter and Change, New York: Mcgraw Hill Education, 2000.

[10] Khairiah dan Rita, D., "Analisis Pengaruh Penambahan Massa Ragi dan Lama Waktu Proses Fermentasi terhadap Nilai Tegangan Listrik Pasta Limbah Kulit Durian (Durino Zibethinus)", vol. 1, no. 2, pp. 16-22, 2017. 
Sumanzaya,dkk:Analisis Karakteristik Elektrik Onggok Singkong sebagai pasta Bio-Baterai 